\title{
The Image of Women and Feminism Ideology in the Novels Written by A. Hasjmy
}

\author{
Khadijah $^{1}$, Ikhwanuddin Nasution ${ }^{2}$, Siti Norma Nasution ${ }^{3}$ \\ ${ }^{I}$ North Sumatera University, Medan, Indonesia \\ ${ }^{2}$ North Sumatera University, Medan, Indonesia \\ ${ }^{3}$ North Sumatera University, Medan, Indonesia
}

\begin{abstract}
The purpose of this study is to find out the image of women in the novels written by A. Hasjmy. The novels to be observed are Melalui Jalan Raya Dunia (1939). In both novels the women faced the problems of poverty and the problems of patriciarchal culture. The image of women portrayed is so hopeless, weak and dependent. The novels are regarded as local color for they talked about women in Aceh related to their culture (talking about ethnicity/including customs, tradition and religion). The method used is descriptive qualitative concerning the data in the form of statements actions and thoughts. The theory applied are sociology of literatur and feminism. Ideology of feminism is needed to analized the problems related to women in domination. After analizing the problems it is hope to find the solutions of the problems as the findings of the research.
\end{abstract}

Keywords: The image of women, feminism ideology, patriarchal culture

\section{Background}

The novel reveals the author's creativity in literature by looking at social phenomena that occur in the community. These phenomena can be either injustice events that violate human rights are usually carried out by the authorities against the common people. In addition, the novel is also able to express a variety of social problems that harm humans as a result of growing ideology in public life such as the uncertainty of life. the search for identity and so on.

Indonesian does not just form a vision by absorbing realities categorically. Writers as social beings, inevitably always interact with the social, political, economic and intellectual where ever s/he is (Sapari, 1985: 283).

A creative writer with imagination and fantasy are added to the data process of social reality. According Teeuw (1994: 230) an author often take pains, through paintings of nature, characters and human faces, the details of time etc., in making it as close as the possible realities. It is also done by A. Hasjmy the author. In his novels. A. Hasjmy reveals social phenomena of his time such as, stories about women's life in Aceh. In particular, the study discussing the image of women as well as ideological feminism which is portrayed as the image of women in Aceh and the values of tradition. They are important talk because until today women's issues related to the image of women in society are still on going. The problems of women do not only cause by external factors but also by internal factors as well. Many women live depend on other people, including their husbands for they believe their function are just a supplement in the family. She does not think about life for herself. She believes that her life purpose is to serve the family and this is expected by a patriarchal culture society. This kind of thinking is still maintained in the community. Therefore, the results of this study are expected to help change the mindset and attitude of both men and women to respect the position and the role of men and women in order to live as equals with their partners i.e. men.

\subsection{Specific Objectives}

The specific objective of this research is to analyze the image of women portrayed in one of A. Hasjmi's novels.

\subsection{Scope of The Research}

The scope of this research is limited on the lives of women in the domestic and public sphere.

Women's Image and issue will be examined through the perspective of feminist ideology.

\section{The Basis of the Theory}

Elizabeth (1973: 14) announced this comprehensive view of human relations and of relations between men and the universe implies the possibility of an ideal of humanity. It is this which inclines me to distinguish it from the type of collective consciousness which I have called ideological by attaching to it the term 'world view'. 
Genetic structuralism theory used in the literature elements such as character, theme, setting or background, and so on. All these elements are connected to each other, given meaning by way of interpretation so that it gets the meaning of the whole. Gordon and Kreiswirth (1977: 10) said he wanted his audience to be able to "fix and grasp a sense of the totality of women's lives and the realities of which they have been a part". Feminist theory is used to relate to the struggle for gender equality and the fight against patriarchal culture. The ideas and thoughts of feminist activists associated with the problems studied.

In interpreting the meaning of the novel which became a source of data, hermeneutic approach is being used. A hermeneutic approach is used to understand a literary work fundamentally and deeply with the principles of interpretation. Moleong (2011: 278) argues hermeneutical is an attempt to make meaning of an object of study clears.

\section{The Women's Image Describes In The Novel}

\section{Data Analysis}

Melalui Jalan Raya Dunia (MJRD) is a family story about a husband and wife in Acehnese society. The story begins with a divorce between a husband and wife in a family. Husband and wife named Nurdin and Asma. The divorce caused by Asma's parents. They are not happy to see their son in law suddenly become poor. Asma has been trying to persuade her husband not to leave but he ignores her plead. Her husband leaves her with a five-month-old baby.

Asma is soluble in the long loneliness and sadness. But she remembers her son therefore she should get to her feet and raises her child. She looks after the child with love and affection. Many obstacles she has to face alone having her life without a husband at her side. Inspite of the obstacles that she has to face, Asma remains strong. She is hoping that her husband will come back to her and she refuses to remarry. Her father and mother are very concerned about Asma's state. They regret all the events they create for Asma and her husband but regret is of no use anymore for Asma. Asma wants him to know that her father and mother regret their deeds. Asma become sickly when the child has grown and has become a useful person to his family and society. Eventually Asma died in waiting for the return of her husband.

\subsubsection{Economic Factors Causing Problems}

When they got married, both Nurdin's and Asma's parents were wealthy. Nurdin's father was a successful merchant who had tens of thousands worth of treasures, so was Asma's. However, God decided differently. Nurdin's father became bankrupt, all his possessions moves into the hands of another person. It is thus natural effects, changing, shifting from one state to another. Once it is flooded, the banks of the river will also move, won't it? Woe to those who are narrow minded who suspect that the moon will be full forever. (MJRD: 13).

It can be seen from the quotes above that Nurdin and Asma came from wealthy families. The parents of the couple were rich when their marriage vows were pronounced. Over time Nurdin's family become bankrupt. His parents treasures move to the hands of others. Properties owned are not always being eternal for humans. God can take them back anytime. One should think that the treasure is on loan from God. A man who thinks that his wealth will be owned solely by him forever will be the losers.

From the above quotation we can see that Asma parents adore wealth. They are happy to have a rich son-in-law. Parents serve the son-in-law on the consideration of treasure. When the son in-law became poor, as is the case in Nurdin. Asma's parents immediately changed their attitude towards Nurdin. Nurdin was no longer treated nicely. He is in contempt and no longer respected by his parents in law

From the above explanation, the root of the problem can be seen. Economic factors caused the separation of Asma and Nurdin. This phenomenon is universal because people still give priority to the socioeconomic strata similarity can coexist in harmony. Faruk (2009: 26) The efforts of the ruling classes to maintain their economic status, social relationships that exist in a certain condition, allowing the establishment of various social institutions such as law, politics, religion, arts, families, and so forth that sustains the relationships.

Universally, people still think prosperity increases a family social status. Therefore, couples who do not come from the same socio-economic status may not be able to coexist in harmony. Many examples are described in the novel as well as those derived from real-world experience. Teen couples's unequal economic life or social status has caused human tragedies. They are victims of social construction, wasted and marginalized.

What a pity! Outside Asma's soul, in which only one body around it, there are two other souls, there are two other bodies, which is far different from the self and the establishment of Asma, the father and mother. The fate that had put out the lantern light of Nurdin's family life happiness, has been putting out too light flickering mind in the soul of the father and mother of Asma, so that the position of Nurdin in their hearts has been moved to a corner of a very narrow and dangerous area. Obviously Nurdin does not present anymore in the 
eyes of their materialistic view. Their complaints and regrets, their hearts are already often heard, because their daughter married to Nurdin. (MJRD: 13). .

From the quote above it can be seen that Asma is not able to resist the will of her parents. Asma and her parents look very different in this life. Both of her parents see property as a destination for everything. When Nurdin's impoverished status within the family become lowly and marginalized. Asma's parents often use languages of insult to Nurdin. While Asma is not looking treasure in this life. he only expects generous and faithful husband to her. The attitudes of the Asma's parents have made their domestic harmony reduced.

Nurdin, a young man who are patient and has a steadfast mind is able to hold his feelings. There is no impression on his face, nothing is too memorable on his face. His broken hearted will not be shown to his wife, the kind and noble heart asma. Let him alone to suffer. But Asma, a sensitive person, can feel what her husband feels, can see what is hidden in the soul of her husband. With a gentle voice, persuades her husband, she entertain her with sweet talk because the real wife's pleasure of life is the true husband's pleasure. (MJRD: 14)

From the quote above it can be seen how much attention a wife gives to her husband. She feels the feelings that are stored in her husband's heart. At a time when her husband is feeling burdened in his soul she feels his distress. She immediately comforts him. She persuades her husband to be gentle. Asma also entertains him with flattery and loving behavior. That he does it based on the philosophy of the happiness of the husband is also the happiness of the wife.

There is a quote in the novel suggesting that the relationship between husband and wife is in harmony. They respect each other no visible symptoms of oppression and domination of a husband to his wife, excerpt below shows a good relationship between husband and wife. A wife can ask her husband about domestic problems.

"I am concerned that you tranquility and serenity will get choppy" said Assam plainly. (MJRD: 15)

From the excerpt below can be seen that Man can only plan so that marriage can be continue until the end of one's life. Nurdin and Asma marriage do not run as expected. Fate dictates differently. At the age five months of their child Nurdin leaves his wife and child. Such an event is breaking the human's heart, it is very sad. They are expecting their family life to be beautiful and bustling with the birth of the child but it turned into contempt as the wheel of life is governed by the Almighty.

"However, fate does not let their hope's wheel spins in the direction they desire. Five months after the birth of their son, comes the above incident, touching the hearts of humanity events; Nurdin leaves his wife and son. Indeed people's lives are not in their own control. It is controlled by the invisible hand of the almighty. If man determines the purpose of the ark of life, certainly it will not look like this form of 'natural, not like this virtual romance. We will find a world filled with tranquility and peace, which is gold-plated with delight and joy". (MJRD: 12).

From the quote below some members of the public can see with their own eyes that Asma and Nurdin family life will be destroyed because the presence of signs of destruction are very strong.

The community in this novel does not believe in anything without looking at the facts. Community life with a harmonious relationship between fellows. Everything happens to members of the community is responded positively. Society does not exaggerate the problem. They see to a problem carefully.

"But those who can see up close, that his eyes up to the vagaries of their buildings would not be surprised to see the palace were broken down by a storm. Because lately, there has been an imagined signs of a hurricane blowing all-powerful building around, which can destroy the very mighty mountain?” (MJRD: 12).

\subsubsection{Women's Image in the Society}

Author expressing his intent and purpose also using the language of symbols, in this case he uses the word building, habitable, instead of the self and the body of the main character Asma. While 'habitable' refer to someone who can fill the heart and soul of Asma. Knocking the door indicates that there are people who are trying to approach Asma, whereas 'self-relegating' means a desire to be alone, She is faithfully waiting for the return of her husband. According to Harun (2009: 156) in view of the Acehnese "faithfullness" interpreted as a determination or courage to love someone sincerely something that goes through boundaries of space and time. it can be seen in the excerpt below.

"It's been many times that the inhabited building have received proposal, by knocking on the door, but Assam has been self-relegating. She did not want to allow people to ride. For her, Nurdin is the only one on the world. If Nurdin has gone, his son who became instead (MJRD: 16).

In this case it seems that Asma resolute, yet no one can replace her husband position in her heart, she just wants accompanied by her child alone.

If we connect with the ideology of feminism women are demanding the freedom to determine the direction of their life. Many women want to live to be independent economically and socially. Women's life does not depend or controlled by anyone even by her own family. Women have the right to choose the way of life to evoke 
herself in accordance with the teachings of Islam which forbids to force a woman to be married. This is in accordance with the opinion Athibi (1998: 181) a father is obliged to consult his daughter on her marriage.

\subsubsection{Relationship with the Environment}

"The events that occurred in Asma's family immediately spread around the village; it has been received with astonishment and full of question marks. No one thought that a strong and peaceful building will be collapse suddenly. Seulimeum dwellers, even the dwellers of villages located at the foot of the mountain Selawah including male populations hardly believe in this event. As long as they know, Nurdin and Asma is a pair to be the model of their social order and peace. The world is strange and magical!" (MJRD: 12).

From the quote above it can be noted that Asma and her family are closely connected to the surrounding community therefore the changes that occur in the family can be seen by neighbors. This shows the community environment is still concerned with issues affecting Asma's families. This is in contrast to the life of the individual in big cities at society where neighbors do not care about neighbors. They are just busy with their families and grow up to become selfish individuals. This novel portrayed the people of Aceh who are still concerned of one another; it is not a negative trait. It does not mean to interfere with other people's business. In the Islamic religion it is emphasized that the neighboring house located within 40 houses from one's house. One should not not let any neighbors suffer from hunger and ignore by the environment.

According to the sociological theory of literary, novels reflect the way of life where the novel was being created. Endraswara (2011: 77) argues social life will lead to the birth of a literary work. A successful literary work or work that is able to reflect its era. The social reality that is expressed in the novel is not much different from the picture with the real day-to-day life in this case the people of Aceh. The author tries to reveal the habits and lifestyle of the society depicted in the novel. Picture of the society which can be disclosed consistent with the idea and intention of the author but there is also the attitude of the people who deviate are not in accordance with the author's thoughts. This is due to the author emphasizing the idea to change the attitude and mindset of the people he describes. This is related to the social function of a literary work that is instilling new ideas and new thinking in accordance with the author's purpose

\section{Conclusion}

Study of feminism on the image of women in the novel A. Hasjmy reveals that the main character Asma is powerless against the attitude of her both parents. The main character has been trying to persuade and seduce with all her love to her husband so that the husband forgets the bad treatments of both of parents towards him. But it does not work. Her husband left her just like that. The study of Feminism towards women's image shows that a patriarchal culture has a negative impact on women which cause a lot of suffering.

\section{Reference}

[1]. Athibi, Ukasyah. 1998.Wanita Mengapa Merosot Akhlaknya. Jakarta: Gema Insani Press.

[2]. Elizabeth, Tom Burns (Ed). 1973. Sociology of Literature and Drama. Middlesex: Penguin books.

[3]. Endraswara, Suardi. 2011. Metodologi Penelitian Kebudayaan. Yogyakarta: Gadjah Mada University Press.

[4]. Faruk. 2009. Pengantar Sosiologi Sastra dari Strukturalisme Genetik sampai Post-modernisme. Yogyakarta : Pustaka Pelajar

[5]. Groden, Michael dan Martin Kreiswirth (ed). 1997. Feminist Theory and Criticism. London: The Johns Hopkins University Press.

[6]. Harun, Mohd. 2009. Memahami Orang Aceh. Bandung: Citapustaka Media Perintis.

[7]. Maleong. J. 2011. Metode Penelitian Kualitatif. Bandung:. Remeja Rosdakarya.

[8]. Sapari, Gunoto. 1985. Sastra Universal juga Kontekstual. Dalam Heriyanto, Ariel. Perdebatan Sastra Kontekstual. Jakarta: Rajawali.

[9]. Teeuw, A. 1984. Sastra dan Ilmu Sastra. Jakarta: PT Dunia Pustaka Jaya. 